\title{
The Archaeological Conservancy: Ten Years of Preservation Success and the New Landowner's Preservation Partnership Program
}

Bonnie C. McKee

Unknown

Follow this and additional works at: https://scholarworks.sfasu.edu/ita

Part of the American Material Culture Commons, Archaeological Anthropology Commons, Environmental Studies Commons, Other American Studies Commons, Other Arts and Humanities Commons, Other History of Art, Architecture, and Archaeology Commons, and the United States History Commons

Tell us how this article helped you.

This Article is brought to you for free and open access by the Center for Regional Heritage Research at SFA ScholarWorks. It has been accepted for inclusion in Index of Texas Archaeology: Open Access Gray Literature from the Lone Star State by an authorized editor of SFA ScholarWorks. For more information, please contact cdsscholarworks@sfasu.edu. 


\section{The Archaeological Conservancy: Ten Years of Preservation Success and the New Landowner's Preservation Partnership Program}

\section{Creative Commons License}

\section{(c) (1) \&}

This work is licensed under a Creative Commons Attribution-NonCommercial 4.0 International License 


\title{
THE ARCHAEOLOGICAL CONSERVANCY: \\ Ten Years of Preservation Success and the New Landowner's Preservation Partnership Program
}

\author{
Bonnie C. McKee
}

The Archaeological Conservancy, the only national nonprofit organization dedicated solely to the acquisition of cultural resource sites for preservation and future research, celebrated ten years of operation in January 1990. Since its founding, the Conservancy has acquired 57 sites in eleven states. In the Caddoan Cultural Area, the Conservancy currently owns four sites (Grobin Davis in Oklahoma [34MC253], and Hale [41TT12], Fasken [41RR14], and Hudnall-Pirtle [41RK4] in Texas) and holds a conservation easement for Cabe Mounds (41BW14), near Texarkana, Texas.

While the Conservancy's major focus for permanent preservation is the acquisition of sites to hold as archeological preserves, professional archeologists may be permitted to conduct research on Conservancy holdings by submitting a valid research design for board approval. All Conservancy preserves in Northeast Texas will be actively managed under the guidelines of a 100 year management plan which will be individually drafted for each site, and will include the participation of a committee of active professional and avocational archeologists.

The Conservancy staff and board realizes that it is not possible for preservation organizations and agencies to hold title to the major portion of Caddoan sites, and has thus been concerned about many sites under private ownership where protection and preservation is often negligent as a result of lack of knowledge and expertise. To rectify this situation and to establish communications with site owners who are not amenable to selling or donating property, the Conservancy board approved a new program at their 1989 summer meeting.

The Landowner's Preservation Partnership (LPP) is designed to draw landowners into active partnership in the preservation of their sites. The Conservancy staff will assist owners with the preservation, protection, and management of their sites. The LPP is, in essence, a "gentleman's agreement" since it carries no legal standing or financial obligations. When a landowner becomes a participating partner, he/she agrees to: (1) inform the Conservancy of any intent to sell or transfer title, (2) inform the Conservancy of any changes in site condition, (3) not impact the site by any kind of activity, (4) protect the site and not allow looters access, and (5) allow Conservancy staff or an appointed representative to visit the site on a periodic schedule.

Under the Landowner's Preservation Partnership program, the Conservancy agrees to: (1) assist the landowners in protection, preservation, and management of their sites, (2) visit the landowners and the sites on a periodic schedule, and (3) provide educational materials which may be of interest to the landowners.

The implementation of this program will provide an opportunity for the Conservancy and the archeological community to stay abreast of site conditions, and to stay in contact with current title holders. All too often, we only learn of a site after it has been destroyed when an owner decides to change land use, or when the natural elements are allowed to take their toll. Additionally, when someone decides to sell their land, it is hoped that the Conservancy will have the opportunity to receive the site by donation or through an agreeable purchase. Howeve, should acquisition still not be possible at the point of sale, the Conservancy staff will pursue enlisting the new owner in the program. 
Experience has proven that often landowners are not knowledgeable about the importance of their sites, and in cases where they have had contact with archeologists, they often receive the impression that their sites are not really so important because communication is usually not continuously maintained. Furthermore, landowners sometimes feel their ownership rights are threatened if they permit access to their sites. There is a real fear among some landowners that the "government will take it away!" The Landowner's Preservation Partnership program is designed to alleviate these concerns by establishing a trusting and cooperative spirit in which landowners develop pride in ownership of a significant site and are active in all aspects of the management and preservation of their sites.

Each landowner who becomes a partner will receive a certificate, and a plaque, in appreciation and recognition of their individual cooperation and stewardship. In the future, a newsletter especially for these partners will be developed which will focus on issues pertinent to privately owned sites as well as on the promotion of education about archeology, cultural resource site importance, and individual stewardship. 